\title{
Artemisia iwayomogi Extract Attenuates High-Fat Diet-Induced Obesity by Decreasing the Expression of Genes Associated with Adipogenesis in Mice
}

\author{
Yeji Choi, ${ }^{1}$ Yasuko Yanagawa, ${ }^{1}$ Sungun Kim, ${ }^{2}$ Wan Kyunn Whang, ${ }^{2}$ and Taesun Park ${ }^{1}$ \\ ${ }^{1}$ Department of Food and Nutrition, Yonsei University, 50 Yonsei-ro, Seodaemun-gu, Seoul 120-749, Republic of Korea \\ ${ }^{2}$ College of Pharmacy, Chung-Ang University, 221 Heuksuk-Dong, dongjak-gu, Seoul 156-756, Republic of Korea \\ Correspondence should be addressed to Taesun Park; tspark@yonsei.ac.kr
}

Received 17 October 2012; Accepted 20 December 2012

Academic Editor: Ravirajsinh N. Jadeja

Copyright ( $\odot 2013$ Yeji Choi et al. This is an open access article distributed under the Creative Commons Attribution License, which permits unrestricted use, distribution, and reproduction in any medium, provided the original work is properly cited.

\begin{abstract}
The objective of the present study was to determine whether Artemisia iwayomogi (AI) extract reduces visceral fat accumulation and obesity-related biomarkers in mice fed a high-fat diet (HFD), and if so, whether these effects are exerted by modulation of the expression of genes associated with adipogenesis and inflammation. AI extract supplementation for 11 weeks significantly prevented HFD-induced increments in body weight, visceral adiposity, adipocyte hypertrophy, and plasma levels of lipids and leptin. Additionally, AI extract supplementation resulted in downregulation of adipogenic transcription factors (PPAR $\gamma 2$ and $\mathrm{C} / \mathrm{EBP} \alpha$ ) and their target genes (CD36, aP2, and FAS) in epididymal adipose tissue compared to the HFD alone. The AI extract effectively reversed the HFD-induced elevations in plasma glucose and insulin levels and the homeostasis model assessment of insulin resistance index. Furthermore, the extract significantly decreased gene expression of proinflammatory cytokines (TNF $\alpha$, MCP1, IL-6, IFN $\alpha$, and INF $\beta$ ) in epididymal adipose tissue and reduced plasma levels of TNF $\alpha$ and MCP1 as compared to HFD alone. In conclusion, these results suggest that AI extract may prevent HFD-induced obesity and metabolic disorders, probably by downregulating the expression of genes related to adipogenesis and inflammation in visceral adipose tissue.
\end{abstract}

\section{Introduction}

Adipogenesis is the process by which mesenchymal precursor cells differentiate into adipocytes [1]. Although its presence is necessary in many ways, excess adipose tissue is associated with serious health problems such as obesity, cardiovascular disease, and type 2 diabetes $[2,3]$. Presently, CCAAT/enhancer binding protein $\alpha(\mathrm{C} / \mathrm{EBP} \alpha)$ and peroxisome proliferator-activated receptor $\gamma 2$ (PPAR $\gamma 2$ ) are considered the 2 primary transcription factors that mediate adipogenesis. It has been reported that inactivation of PPAR $\gamma 2$ and $\mathrm{C} / \mathrm{EBP} \alpha$ in adipose tissue protects against obesity in rodent models [4-6]. Thus, potential therapeutic agents that have the ability to inhibit adipogenesis could have a profound impact as a strategy for preventing obesity and related metabolic disorders.
Adipose tissue not only serves as an organ for energy storage, but also as an endocrine organ by releasing various inflammatory cytokines such as tumor necrosis factor $\alpha(\mathrm{TNF} \alpha)$ and interleukin- (IL-)6 [7-9]. Proinflammatory molecules produced by adipose tissue have been implicated as active participants in the development of inflammation and the increased risk of obesity-related insulin resistance [9-11]. Increased production of monocyte chemoattractant protein 1 (MCP1), interferon (IFN) $\alpha, \operatorname{IFN} \beta, \operatorname{TNF} \alpha$, and IL- 6 in adipose tissue has been reported in animal models of obesity $[8-10,12]$. Therefore, therapeutic agents that attenuate proinflammatory cytokines may prove useful in the medical management of obesity-induced inflammation.

Artemisia iwayomogi (AI), a member of Compositae, is a perennial herb easily found throughout Korea. It has been used as a traditional medicine and is known to have 
antiallergic, antiapoptotic, and antioxidant effects [13-16]. It has been reported that a carbohydrate fraction from AI suppresses spontaneous or 2,3,7,8-tetrachlorodibenzo-pdioxin-induced apoptotic death of mouse thymocytes [14, 15]. Artemisia iwayomogi extract displays scavenging activity of peroxynitrite, a potent cytotoxic oxidant formed by the reaction between nitric oxide and superoxide radicals [16]. In addition, to our knowledge, few studies have described the beneficial effects of AI in high-fat diet-(HFD-) fed obese rodents. One study reported that oral administration of AI extract significantly reduced serum lipid levels in HFD-fed rats [17]. A recent study by Cho et al. reported that oral administration of AI extract to HFD-fed mice provoked upregulation of PPAR $\beta$ and its target genes involved in fatty acid oxidation in the skeletal muscle [18]. To date, however, no study has assessed the protective effects of AI extract on adipose tissue dysfunction in diet-induced obese animal models. Therefore, the present study aimed to investigate whether AI extract could reduce visceral fat accumulation and improve obesity-related biomarkers in HFD-fed mice, and if so, whether these effects were exerted by modulation of the expression of genes associated with adipogenesis and inflammation.

\section{Material and Methods}

2.1. Preparation of AI Extract. Artemisia iwayomogi was collected from Korean standard products in March 2008, and was identified by Professor Wan Kyun Whang of the Pharmaceutical Botany Laboratory at Chung-Ang University in Seoul, Republic of Korea, where a voucher specimen has been deposited. Dried AI (500 g) was washed in water, oven dried at $40^{\circ} \mathrm{C}$, mechanically fragmented, and then was powdered in an electric mill. The powder was extracted 5 times with ethanol (powder: solvent $=1: 5$ ) at room temperature. After filtration, the extraction was vacuum concentrated to yield $6.25 \%$ ethanol extract ( $31.3 \mathrm{~g}$ ), which was stored at $-4^{\circ} \mathrm{C}$ until use.

2.2. HPLC Analysis. Chromatography was performed using a Water HPLC system (Water Corporation, Milford, MA, USA) with an autosampler. HPLC separation was conducted using a Kromasil C18 column $(4.6 \mathrm{~mm} \times 250 \mathrm{~mm}, 5-\mu \mathrm{m}$ inner diameter) at $30^{\circ} \mathrm{C}$ with a flow rate of $1.0 \mathrm{~mL} / \mathrm{min}$ using a gradient mobile phase composed of water (A) and acetonitrile (B). The mobile phase comprised an $80: 20$ mixture of component $\mathrm{A}$ to $\mathrm{B}$ as the initial condition of the chromatographic run, and component $\mathrm{B}$ was increased to $80 \%$ in a linear gradient in $30 \mathrm{~min}$. The sample injection volume was $10 \mu \mathrm{L}$. The identities of the compounds in the AI extract were confirmed by ${ }^{1} \mathrm{H}-\mathrm{NMR},{ }^{13} \mathrm{C}-\mathrm{NMR}$, and $\mathrm{MS}$, with individual purities of not less than $95 \%$.

2.3. Animals and Experimental Protocol. Male C57BL/6J mice ( 5 weeks old) were purchased from Orient Bio (Gyeonggi-do, Republic of Korea) and were maintained in $12 \mathrm{~h}$ light/dark with ad libitum access to food and water. After a 1 -week acclimatization period, the mice were divided into 3 groups ( $n=10$ per group): normal diet (ND), HFD, and
0.5\% AI extract-supplemented diet (AED). The ND was a purified diet based on the AIN-76 rodent diet composition. The HFD was identical to the ND, but to which $200 \mathrm{~g}$ fat $/ \mathrm{kg}$ ( $170 \mathrm{~g}$ lard plus $30 \mathrm{~g}$ corn oil) and $1 \%$ cholesterol had been added. The AED was identical to the HFD but contained $0.5 \%(\mathrm{w} / \mathrm{w})$ AI extract. The mice were fed the experimental diets for 11 weeks. Diet consumption was monitored daily, and body weight was monitored weekly. At the end of the feeding period, mice were anesthetized with diethyl ether after an overnight fasting for $16 \mathrm{~h}$, and their blood samples were collected in EDTA-coated tubes. Plasma samples were isolated by centrifugation at $4000 \times \mathrm{g}$ for $20 \mathrm{~min}$ and stored at $-80^{\circ} \mathrm{C}$ for subsequent analysis. Adipose and liver tissues were collected, washed with phosphatebuffered saline, and frozen at $-80^{\circ} \mathrm{C}$. All animal experiments were performed in accordance with the Korean Food and Drug Administration guidelines. The Institutional Animal Care and Use Committee of the Yonsei Laboratory Animal Research Center reviewed and approved the protocols.

2.4. Biochemical Analysis. Plasma concentrations of triglycerides (TGs), free fatty acids (FFAs), glucose, total cholesterol, and HDL cholesterol were measured using commercial kits (Bio-Clinical System, Gyeonggi-do, Republic of Korea). LDL + VLDL cholesterol levels were calculated by subtracting HDL cholesterol from total cholesterol. Plasma insulin levels were analyzed using a mouse insulin ELISA kit (ALPCO Diagnostics, Windham, NH, USA). The homeostasis model assessment of insulin resistance (HOMA-IR) index was calculated as fasting plasma glucose concentration ( $\mathrm{mmol} / \mathrm{L}$ ) multiplied by fasting insulin level ( $\mathrm{pmol} / \mathrm{L}$ ) divided by 22.5 . Plasma levels for leptin, TNF $\alpha$, and MCP1 were measured using a mouse ELISA kit (ID Labs, Cambridge, MA, USA). Hepatic lipids were extracted as described by Folch et al. [19], using a chloroform-methanol mixture (2:1 v/v), and the dried lipid residues were dissolved in $2 \mathrm{~mL}$ ethanol. Concentrations of cholesterol, triglyceride, and free fatty acids in the hepatic lipid extracts were measured using the same enzymatic kits that were used for the plasma analysis.

2.5. Histological Analysis. White adipose tissues (WATs) were fixed in neutral buffered formalin, embedded in paraffin, and sectioned into $5 \mu \mathrm{m}$ sections onto slides. For histology, sections were stained with hematoxylin and eosin (H\&E). The sectional areas of WAT were analyzed to quantify the size of the adipocytes.

2.6. RNA Extraction and Semiquantitative RT-PCR. Total RNA was isolated from the epididymal adipose tissue of each mouse with TRIzol (Invitrogen, Carlsbad, CA, USA) according to the manufacturer's instruction. Isolated RNA was quantified using a spectrophotometer, and cDNA was synthesized using reverse transcriptase (Invitrogen). The PCR was programmed as follows: $10 \mathrm{~min}$ at $94^{\circ} \mathrm{C}$; $30-33$ cycles at $94^{\circ} \mathrm{C}$ for $30 \mathrm{~s}, 55^{\circ} \mathrm{C}$ for $30 \mathrm{~s} ; 72^{\circ} \mathrm{C}$ for $1 \mathrm{~min}$; 10 min incubation at $72^{\circ} \mathrm{C}$. Four microliters of each PCR reaction were mixed with $1 \mu \mathrm{L}$ of 6 -fold concentrated loading buffer and loaded onto $2 \%$ agarose gel containing ethidium bromide. The GenBank accession numbers of the relevant 
TABLE 1: Primer sequences and RT-PCR conditions.

\begin{tabular}{|c|c|c|c|c|}
\hline Gene description & Primers & Sequences $\left(5^{\prime} \rightarrow 3^{\prime}\right)$ & $T_{m}\left({ }^{\circ} \mathrm{C}\right)$ & Size (bp) \\
\hline \multirow{2}{*}{ Peroxisome proliferator-activated receptor $\gamma 2(\operatorname{PPAR} \gamma 2)$} & $\mathrm{F}$ & TTCGGAATCAGCTCTGTGGA & \multirow[t]{2}{*}{55} & \multirow[t]{2}{*}{148} \\
\hline & $\mathrm{R}$ & CCATTGGGTCAGCTCTTGTG & & \\
\hline \multirow{2}{*}{ CCAAT/enhancer binding protein $\alpha(\mathrm{C} / \mathrm{EBP} \alpha)$} & $\mathrm{F}$ & AAGGCCAAGAAGTCGGTGGA & \multirow[t]{2}{*}{55} & \multirow[t]{2}{*}{189} \\
\hline & $\mathrm{R}$ & CCATAGTGGAAGCCTGATGC & & \\
\hline \multirow{2}{*}{ Adipocyte protein 2 (aP2) } & $\mathrm{F}$ & ACATGAAAGTGGGAGTG & \multirow[t]{2}{*}{55} & \multirow[t]{2}{*}{128} \\
\hline & $\mathrm{R}$ & AAGTACTCTCTGACCGGATG & & \\
\hline \multirow{2}{*}{ Cluster of differentiation 36 (CD36) } & $\mathrm{F}$ & ATGACGTGGCAAAGAACAGC & \multirow[t]{2}{*}{55} & \multirow[t]{2}{*}{160} \\
\hline & $\mathrm{R}$ & GAAGGCTCAAAGATGCCTCC & & \\
\hline \multirow{2}{*}{ Fatty acid synthase (FAS) } & $\mathrm{F}$ & TTGCCCGAGTCAGAGAACC & \multirow[t]{2}{*}{55} & \multirow[t]{2}{*}{171} \\
\hline & $\mathrm{R}$ & CGTCCACAATAGCTTCATAGC & & \\
\hline \multirow{2}{*}{ Monocyte chemoattractant protein 1 (MCP1) } & $\mathrm{F}$ & CCAGCAAGATGATCCCAATG & \multirow[t]{2}{*}{55} & \multirow[t]{2}{*}{450} \\
\hline & $\mathrm{R}$ & CTTCTTGGGGTCAGCACAGA & & \\
\hline \multirow{2}{*}{ Interferon $\alpha(\mathrm{IFN} \alpha)$} & $\mathrm{F}$ & ATGGCTAG(G/A)CTCTGTGCTTTCCT & \multirow[t]{2}{*}{60.2} & \multirow[t]{2}{*}{500} \\
\hline & $\mathrm{R}$ & GGGCTCTCCAGA(T/C)TTCTGCTCTG & & \\
\hline \multirow{2}{*}{ Interferon $\beta$ (IFN $\beta)$} & $\mathrm{F}$ & TGGAGCAGCTGAATGGAAAG & \multirow[t]{2}{*}{55} & \multirow[t]{2}{*}{122} \\
\hline & $\mathrm{R}$ & GAGCATCTCTTGGATGGCAA & & \\
\hline \multirow{2}{*}{ Tumor necrosis factor $\alpha(\mathrm{TNF} \alpha)$} & $\mathrm{F}$ & TGTCTCAGCCTCTTCTCATT & \multirow[t]{2}{*}{55} & \multirow[t]{2}{*}{156} \\
\hline & $\mathrm{R}$ & AGATGATCTGAGTGTGAGGG & & \\
\hline \multirow{2}{*}{ Intereukin 6 (IL-6) } & $\mathrm{F}$ & TTGCCTTCTTGGGACTGATG & \multirow[t]{2}{*}{55} & \multirow[t]{2}{*}{162} \\
\hline & $\mathrm{R}$ & CCACGATTTCCCAGAGAACA & & \\
\hline \multirow{2}{*}{ Glyceraldehyde-3-phosphate dehydrogenase (GAPDH) } & $\mathrm{F}$ & AGAACATCATCCCTGCATCC & \multirow[t]{2}{*}{60} & \multirow[t]{2}{*}{321} \\
\hline & $\mathrm{R}$ & TCCACCACCCTGTTGCTGTA & & \\
\hline
\end{tabular}

templates and forward $(\mathrm{F})$ and reverse $(\mathrm{R})$ primer sequences are shown in Table 1. The measured mRNA levels were normalized to the glyceraldehyde-3-phosphate dehydrogenase (GAPDH) mRNA levels.

2.7. Statistical Analysis. The data on body weight gain, plasma biochemistries, and adipocyte diameter are presented as the mean \pm SEM of 10 mice. RT-PCR results are presented as the mean \pm SEM of at least 3 separate experiments. All analyses were performed using SPSS (version 12.0). Data were analyzed by 1-way ANOVA, followed by Duncan's multiple range tests. $P$ values $<0.05$ were considered significant.

\section{Results}

3.1. Chromatographic Analysis of Artemisia iwayomogi Extract. The HPLC chromatogram revealed that scopolin (AI-I, 1.21\% w/w), acetophenone glycoside (AI-II, $0.26 \%$ $\mathrm{w} / \mathrm{w}$ ), and scopoletin (AI-III, $0.38 \% \mathrm{w} / \mathrm{w}$ ) were the major components among the organic molecules of the AI extract, which exhibited maximum absorbance at $280 \mathrm{~nm}$ (Figure 1 and Table 2).

3.2. Body and Visceral Fat Pad Weights. AED-fed mice exhibited significantly decreased body weight gain $(-52 \%)$ and final body weight (-19\%) compared to HFD-fed mice without their food intake being affected (Figures 2(a)-2(c)).

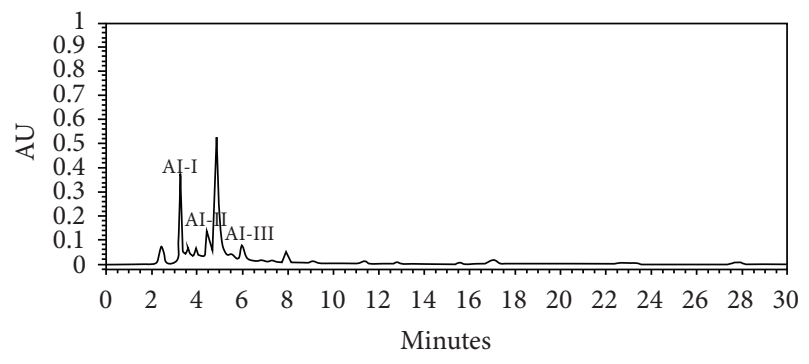

FIGURE 1: HPLC chromatogram of the Artemisia iwayomogi extract. The peaks were assigned based on the isolation of each compound. AI-I: scopolin; AI-II: acetophenone glycoside; AI-III: scopoletin (see Table 2).

The food efficiency ratio (FER) was significantly lower in AED-fed mice (-54\%) compared to HFD-fed mice (Figure $2(d))$. The AI extract supplementation led to a significant decrease in total visceral fat pad weight $(-64 \%)$ compared to the HFD alone. This was attributable to weight decreases in the epididymal $(-54 \%)$, retroperitoneal $(-58 \%)$, perirenal $(-83 \%)$, and mesenteric $(-69 \%)$ adipose depots $(P<0.05$ for all depots; Figures 2(e) and 2(f)). The H\&E sections of epididymal adipose tissues revealed that adipocyte diameter $(-20 \%)$ was significantly decreased in AED-fed mice than in HFD-fed mice (Figure 2(g)). 
TABle 2: Profile of compounds in the Artemisia iwayomogi extract.

\begin{tabular}{|c|c|c|c|}
\hline Compound & IUPAC name & Structure & Contents (\%) \\
\hline (1) Scopolin & $\begin{array}{c}\text { 6-methoxy-2-oxo- } 2 H \text {-chromen- } \\
\text { 7-yl } \\
\beta \text {-D-glucopyranoside }\end{array}$ & & $1.21 \pm 0.07$ \\
\hline $\begin{array}{l}\text { (2) Acetophenone } \\
\text { glycoside }\end{array}$ & $\begin{array}{c}\text { 2,4-dihydroxy-6- } \\
\text { methoxyacetophenone } \\
\text { 4-O- } \beta \text {-D-glucopyranoside }\end{array}$ & & $0.26 \pm 0.01$ \\
\hline (3) Scopoletin & $\begin{array}{l}\text { 7-hydroxy-6-methoxychromen- } \\
\text { 2-one }\end{array}$ & & $0.38 \pm 0.04$ \\
\hline
\end{tabular}

3.3. Plasma Biochemistries. Plasma concentrations of TG $(-47 \%)$, FFA $(-47 \%)$, total cholesterol $(-47 \%)$, HDL cholesterol $(-34 \%)$, and LDL + VLDL cholesterol (-59\%) were all significantly lower in AED-fed mice than in HFD-fed mice $(P<0.05$, Figures 3(a)-3(e)). AED-fed mice had significantly lower plasma concentrations of leptin $(-71 \%)$ than HFDfed mice (Figure 3(f)). Likewise, the AI extract significantly attenuated the elevation in plasma concentrations of glucose $(-42 \%)$ and insulin $(-21 \%)$ in HFD-fed mice (Figures 3(g) and $3(\mathrm{~h}))$. The HOMA-IR calculations revealed that the AI extract significantly decreased the HOMA-IR index (-49\%) compared to HFD alone (Figure 3(i)). AED-fed mice had significantly lower plasma concentrations of MCP1 (-60\%) and $\mathrm{TNF} \alpha(-46 \%)$ than HFD-fed mice (Figures 3(j) and $3(\mathrm{k}))$.

3.4. Hepatic Lipid Accumulation. AED-fed mice had significantly lower liver weight $(-30 \%)$ than in HFD-fed mice (Figure 4(a)). Hepatic triglyceride (-66\%), cholesterol $(-51 \%)$, and free fatty acid $(-75 \%)$ concentrations were markedly lower in AED-fed mice than in HFD-fed mice (Figures 4(b)-4(d)).

3.5. Expression of Genes Related to Adipogenesis. Examination of adipogenic gene expression in epididymal adipose tissue showed that mRNA levels of PPAR $\gamma 2(-44 \%)$ and
$\mathrm{C} / \mathrm{EBP} \alpha(-18 \%)$, regulators of adipogenic molecules, were significantly lower in AED-fed mice than in HFD-fed mice. The expressions of PPAR $\gamma 2$ target genes, including cluster of differentiation 36 (CD36) (-29\%), adipocyte fatty acid binding protein (aP2) (-35\%), and fatty acid synthase (FAS) $(-58 \%)$, were all significantly decreased in AED-fed mice than in HFD-fed mice (Figure 5).

3.6. Expression of Genes Related to Inflammation. Based on the active roles of proinflammatory cytokines in obesityrelated inflammation, we examined the effect of AI extract on proinflammatory cytokine expressions in epididymal adipose tissue. Compared to HFD-fed mice, the epididymal adipose tissue in AED-fed mice contained significantly decreased mRNA levels of several proinflammatory cytokines, including TNF $\alpha(-41 \%)$, IL-6 (-28\%), MCP1 (-32\%), IFN $\alpha$ $(-41 \%)$, and IFN $\beta(-38 \%)$ (Figure 6).

\section{Discussion}

This feeding study was designed to assess whether AI extract supplementation for 11 weeks could improve diet-induced obesity and obesity-related biomarkers in mice. Based on a preliminary study involving different AI extract dosages $(0.5 \%, 1 \%$, and $2 \%)$, we determined that $0.5 \%$ AI extract was the minimal effective dose for preventing weight gain 


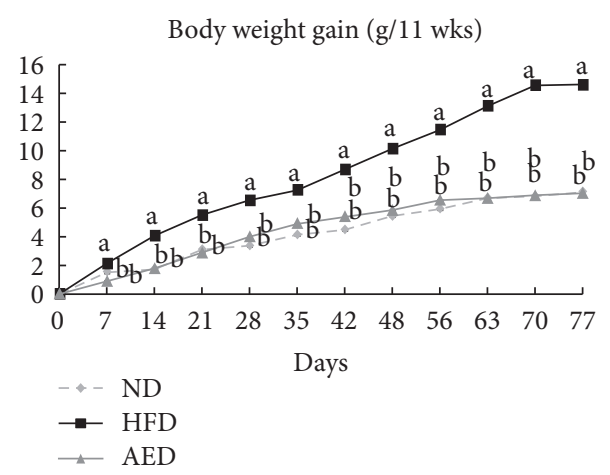

(a)
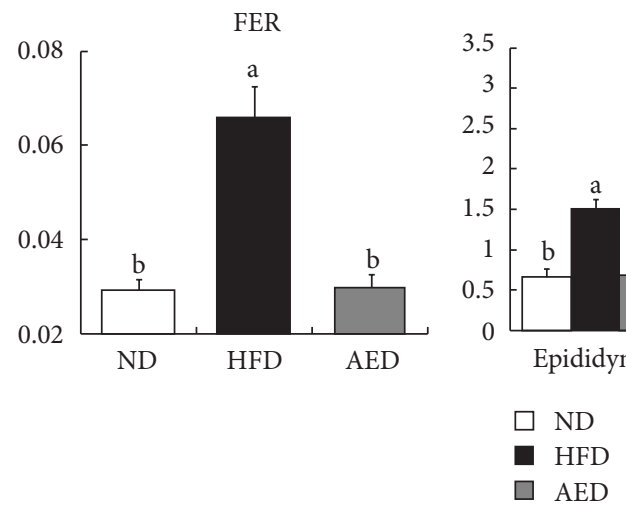

(d)

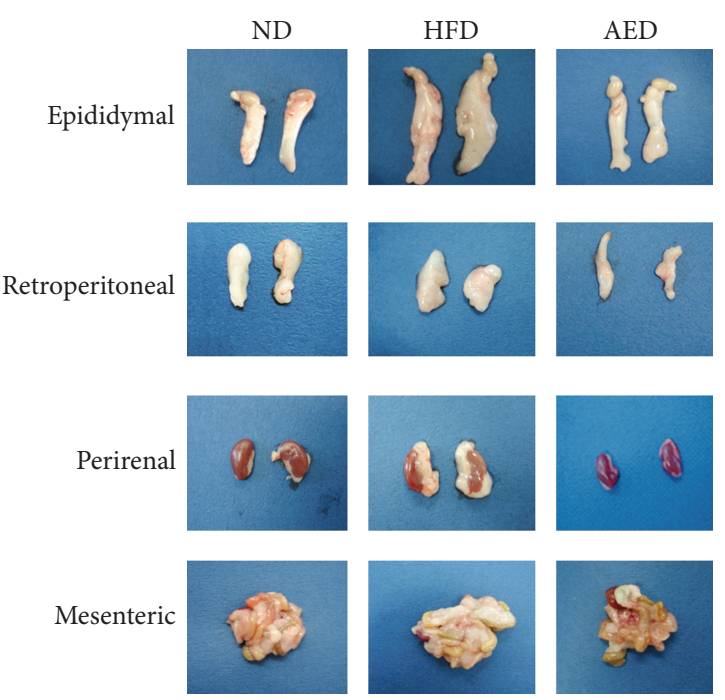

(f)

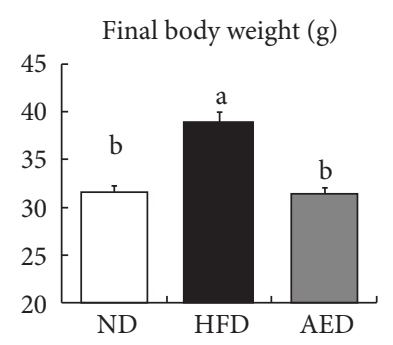

(b)

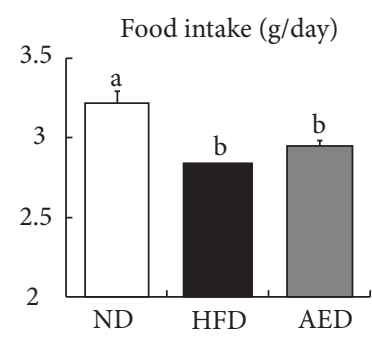

(c)

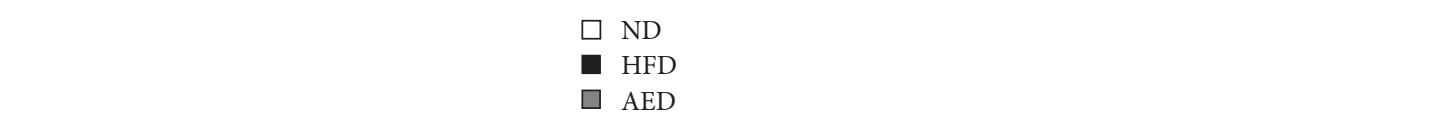

(e)
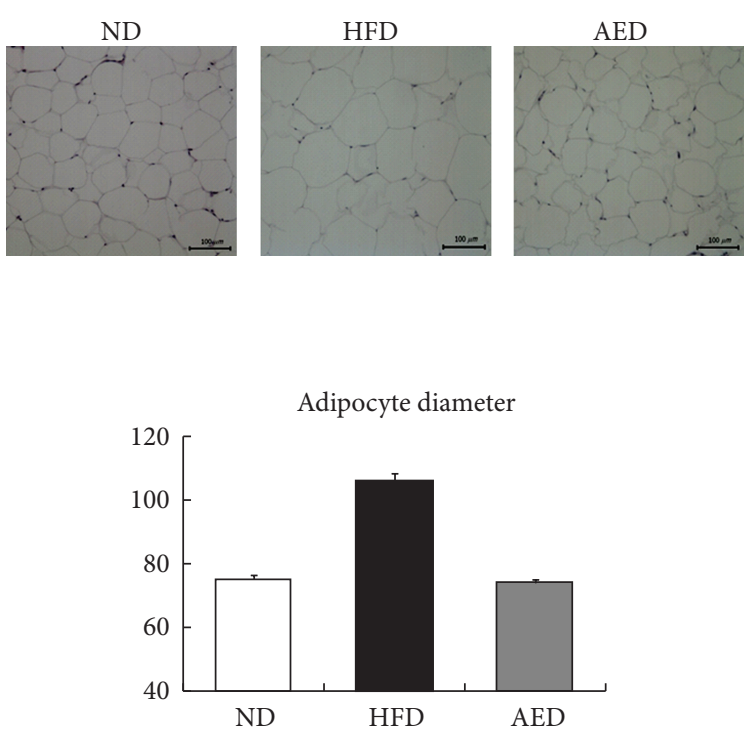

(g)

FIGURE 2: Effects of Artemisia iwayomogi extract supplementation on body weight gain, food efficiency ratio, and visceral fat pad weights of mice fed with high-fat diet. Mice were fed ND, HFD, or AED for 11 weeks. Changes in (a) body weight gain, (b) final body weight, (c) food intake, (d) FER, (e), (f) visceral fat pad weights, (g) representative pictures of H\&E-stained fat cells from mice epididymal adipose tissue $(\times 100)$, and densitometric analysis of adipocyte diameter in epididymal tissue. Data represent mean \pm SEM, $n=10$. Means without a common letter differ, $P<0.05$. FER = (body weight gain for experimental period $(\mathrm{g})) /($ food intake for experimental period $(\mathrm{g}))$.

in HFD-fed mice (data not shown). Hence, the $0.5 \%$ AI extract was considered for this study. In the present study, the AI extract significantly decreased not only body weight gain, but also visceral adiposity and adipocyte hypertrophy in HFD-fed mice. Since visceral adiposity is positively correlated to plasma leptin concentration, the circulating leptin level is an ideal indicator for assessing obesity in both experimental animals and humans $[20,21]$. In this context, 


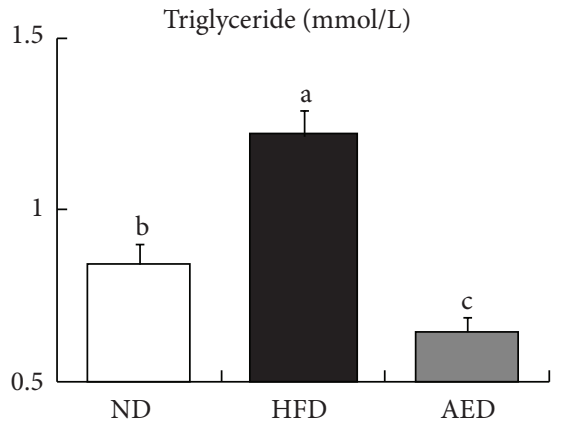

(a)

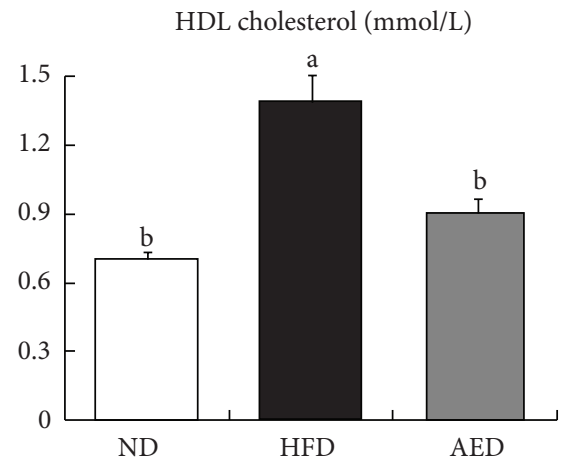

(d)

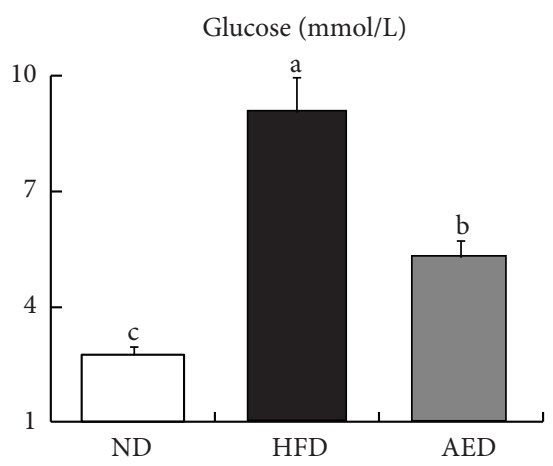

(g)

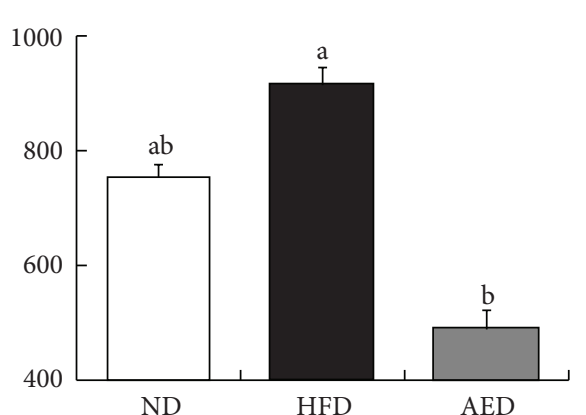

(b)

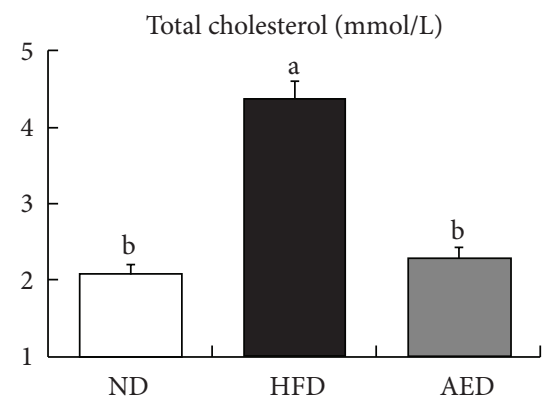

(c)

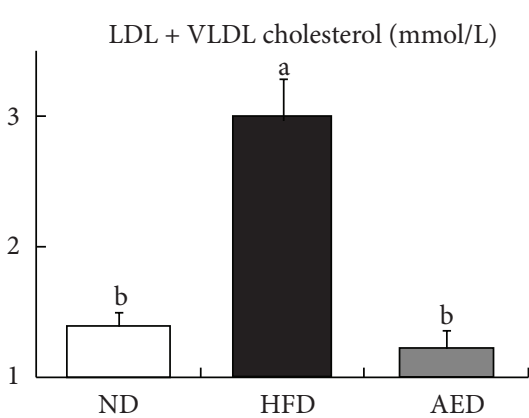

(e)

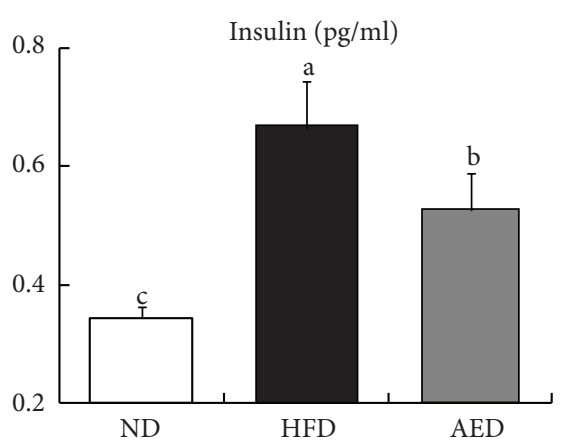

(h)

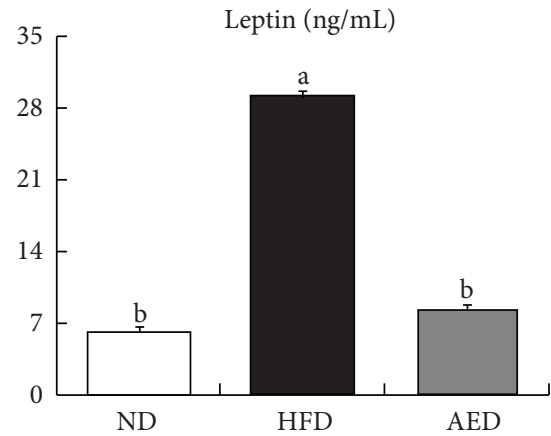

(f)

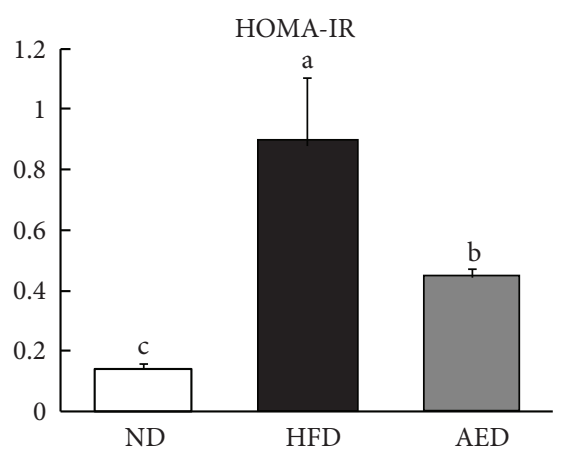

(i)

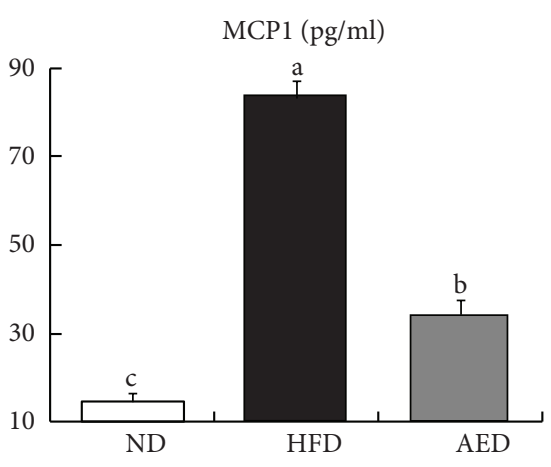

(j)

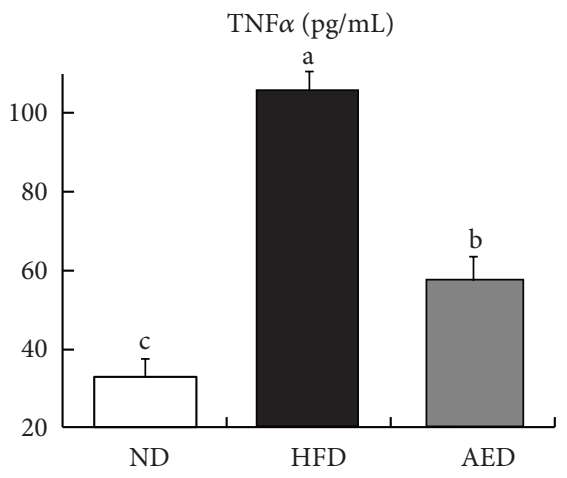

(k)

Figure 3: Effects of Artemisia iwayomogi extract supplementation on plasma levels of lipids, leptin, glucose, insulin, and proinflammatory cytokines in mice fed with high-fat diet. (a) Triglyceride, (b) free fatty acid, (c) total cholesterol, (d) HDL cholesterol, (e) LDL + VLDL cholesterol, (f) leptin, (g) glucose, (h) insulin, (i) HOMA-IR, (j) MCP1, and (k) TNF $\alpha$. Bars represent mean \pm SEM, $n=10$. Means without a common letter differ, $P<0.05$. 


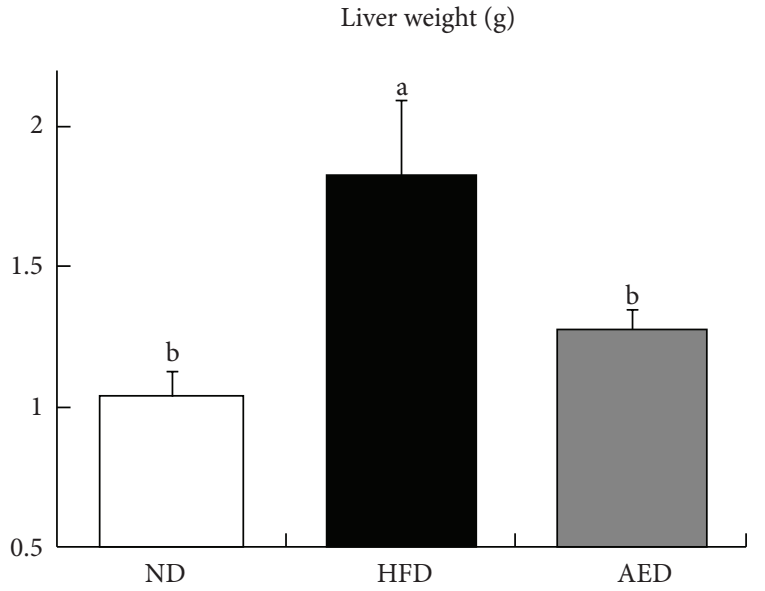

(a)

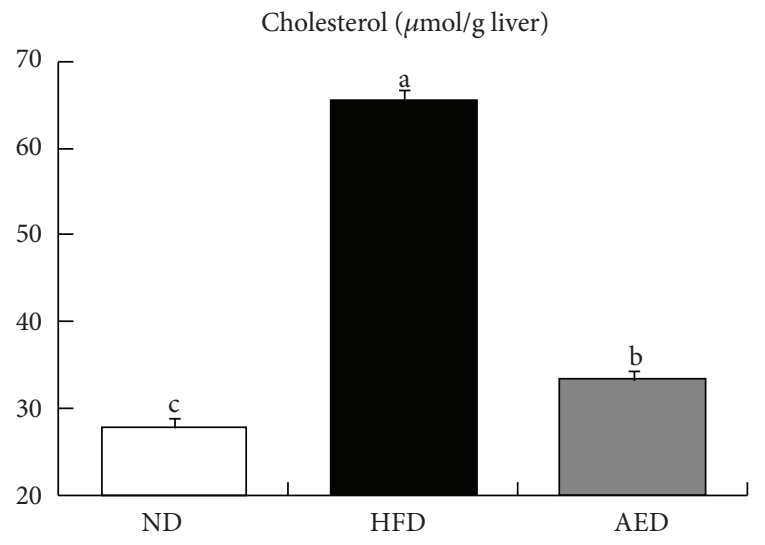

(c)

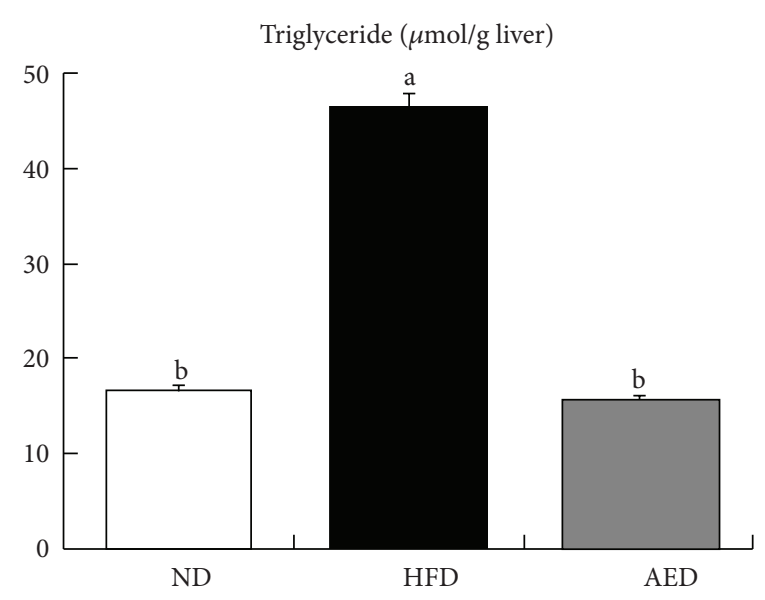

(b)

Free fatty acid ( $\mu \mathrm{Eq} / \mathrm{g}$ liver $)$

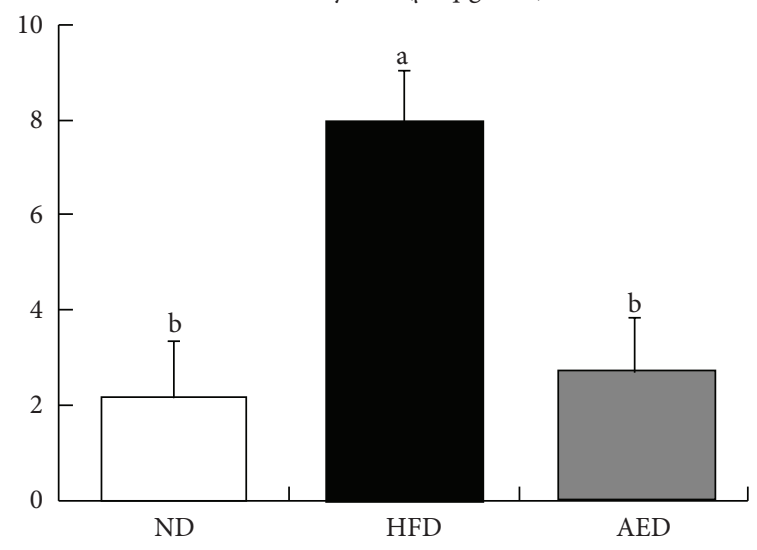

(d)

Figure 4: Effects of Artemisia iwayomogi extract supplementation on liver weights and hepatic lipid levels in mice fed with high-fat diet. (a) Liver weights and concentrations of hepatic (b) triglyceride, (c) cholesterol, and (d) free fatty acids. Means without a common letter differ, $P<0.05$.

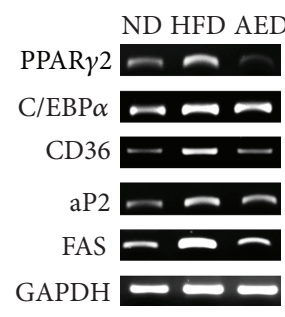

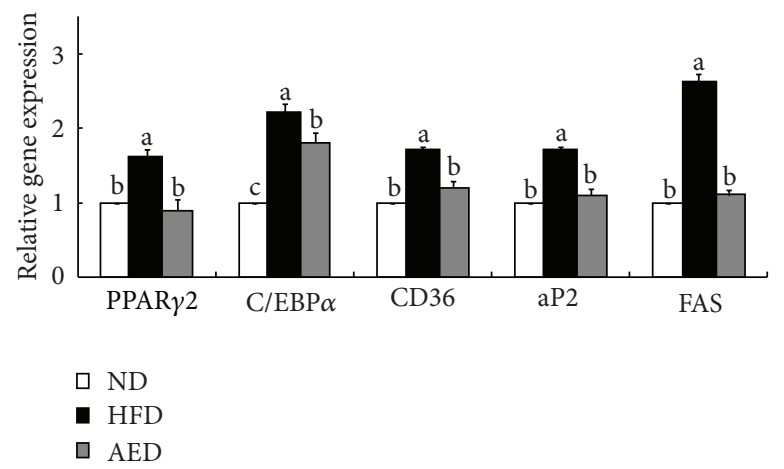

(b)

Figure 5: Effects of Artemisia iwayomogi extract supplementation on genes regulating adipogenesis in epididymal adipose tissue of mice fed with high-fat diet. (a) Representative example of semiquantitative RT-PCR revealing the expression levels of adipogenic genes in epididymal adipose tissue and their quantitative analysis. The data represent relative density normalized to GAPDH. Data represent the results of 3 independent experiments. Bars represent mean \pm SEM. Means without a common letter differ, $P<0.05$. 


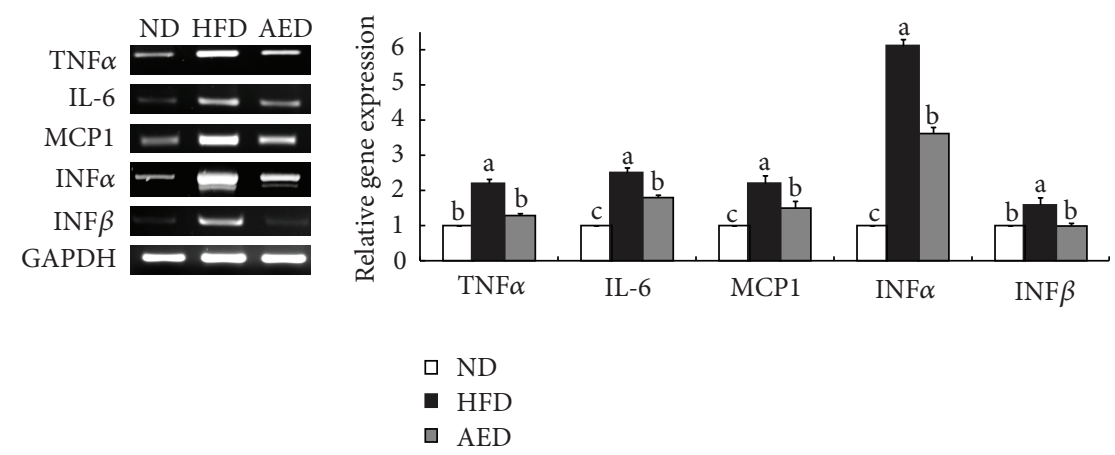

(a)

(b)

FIGURE 6: Effects of Artemisia iwayomogi extract supplementation on expression of proinflammatory cytokine genes in epididymal adipose tissue of mice fed with high-fat diet. (a) Representative example of semi-quantitative RT-PCR revealing the expression levels of proinflammatory cytokines in epididymal adipose tissue and their quantitative analysis. Data represent the results of 3 independent experiments. Bars represent mean \pm SEM. Means without a common letter differ, $P<0.05$.

the lower plasma leptin level recorded in the AED-fed mice may be attributable to the prevention of visceral adipocyte hypertrophy.

As there was no significant difference in food consumption between HFD- and AED-fed mice, the beneficial effects of the AI extract on body weight gain and visceral fat accumulation evidently did not depend on decreased energy intake. Thus, we hypothesized that the AI extract reduced HFD-induced body weight gain and visceral fat accumulation by mediating the inhibition of adipogenesis. That the expression of PPAR $\gamma 2$ and C/EBP $\alpha$ in WAT is upregulated in HFD-induced obese animals is well known [4, 22]. Increased PPAR $\gamma 2$ and $\mathrm{C} / \mathrm{EBP} \alpha$ function cooperatively to transactivate adipocyte genes, including FAS, CD36, and aP2 [23-26]. FAS catalyzes the reactions for the synthesis of long-chain fatty acids [27], whereas CD36 and aP2 facilitate the uptake of long-chain fatty acids in adipocytes [23, 28], thereby increasing adipocyte size and fat accumulation. In the current study, the AI extract significantly reversed the HFDinduced upregulation of adipogenic transcription factors (PPAR $\gamma 2$ and $\mathrm{C} / \mathrm{EBP} \alpha$ ) and their target genes (FAS, CD36, and $\mathrm{aP} 2$ ) in the epididymal adipose tissue of mice. These decreased expressions of adipogenic genes by the AI extract may have contributed to the lower visceral adiposity and body weight gain. In addition, the AI extract significantly decreased plasma FFA levels in HFD-fed mice. As increased plasma concentrations of FFA form a vicious relationship with PPAR $\gamma 2$ activation in diet-induced obese animals [29, 30 ], the decreased FFA level in the AED-fed mice might also be considered associated with PPAR $\gamma 2$ inactivation.

Increased adipose tissue accumulation in obese individuals correlates with the overproduction of proinflammatory cytokines that play crucial roles in the development of obesity-induced inflammation [8, 11]. In obese animals, excess adipose tissue increases the expression and secretion of $\mathrm{TNF} \alpha$, a prototypical inflammatory cytokine $[4,9,12]$. In turn, increased TNF $\alpha$ activates adipocytes, thereby further enhancing the expression of various proinflammatory genes such as MCP1, IL-6, IFN $\alpha$, and IFN $\beta[31,32]$. IL-6 induces a hepatic acute-phase reaction with upregulated acute-phase proteins, including C-reactive protein and fibrinogen [33, 34], whereas MCP1 contributes to macrophage infiltration into adipose tissue, which leads to chronic inflammation [35]. IFN $\alpha / \beta$ directly stimulates IFN $\gamma$ production, a regulator of innate immune response, in $\mathrm{T}$ cells [36]. Our results suggested that the decrease in visceral adiposity by the AI extract might have contributed, in part, to the decreased expression of proinflammatory cytokines (TNF $\alpha$, MCP1, IL6, IFN $\alpha$, and $\operatorname{IFN} \beta$ ) and reduced plasma levels of TNF $\alpha$ and MCP1. Consequently, the decreased gene expression and secretion of proinflammatory cytokines in the AED-fed mice may have contributed to the prevention of obesity-induced inflammation.

Several studies have demonstrated that cytokines play crucial roles in the development of insulin resistance $[35,37-$ 39]. In diet-induced obese animals, increased plasma levels of TNF $\alpha$, IL-6, MCP1, and leptin have been shown to impair the ability of insulin to activate signal transduction and stimulate glucose uptake into skeletal muscle and adipose tissue [35, 37-41]. Thus, in the present study, improvement of insulin resistance by the AI extract might be associated with decreased gene expression and/or production of cytokines such as TNF $\alpha$, IL-6, MCP1, and leptin.

Separation and determination of chemical constituents are generally recommended for standardization and quality control of herbal products and herb-related investigations [42]. Several studies have demonstrated that AI contains flavonoids such as genkwanin and jaceosidin [43], essential oils, including eugenol and 1,8-cineole [44], and coumarin compounds such as scopoletin and scopolin [43, 45]. In addition, scopoletin has been used as a standard compound for the verification and identification of AI [46, 47]. In the present study, we isolated not only scopoletin, but also scopolin and acetophenone glycoside from the AI extract (Figure 1 and Table 2). Of these, scopolin (1.21\%) was the most abundant, followed by scopoletin (0.38\%) and acetophenone glycoside $(0.26 \%)$. In addition, the scopolin content of the AI extract was higher in our study than that 
observed by Kim et al. $(0.49 \% \mathrm{w} / \mathrm{w})$ and Ding et al. $(0.2 \%$ $\mathrm{w} / \mathrm{w})[43,45]$. This difference may be due to the differing extraction and isolation methods as well as differences in plant material $[43,45]$. Previous studies have shown that coumarin compounds from Fraxinus rhynchophylla [48], Angelica gigas [49], and Ionidium suffruticosum [50] inhibit adipocyte differentiation in 3T3-L1 cells and/or reduce body weight gain and plasma lipid levels in mice fed a high-fat diet. Thus, the antiobesity activity of AI extract observed in the present study may be attributable to the presence of high amounts of coumarin compounds in the plant. Further studies are needed to determine the major active compounds in AI extract that are responsible for decreased visceral adiposity and other obesity-related biomarkers.

In summary, the present study showed that AI extract reduced visceral fat accumulation in HFD-fed mice and improved the risk factors related to the metabolic syndrome, such as inflammation and insulin resistance. The evidence obtained in this study suggests that the beneficial effects of AI extract may be due to, at least in part, downregulation of the genes related to adipogenesis and inflammation in the visceral adipose tissue of mice. Therefore, dietary supplementation with this extract, if validated in human studies, may provide an adjunctive therapy for the prevention and/or treatment of obesity and metabolic syndrome.

\section{Abbreviations}

$\begin{array}{ll}\text { AI: } & \text { Artemisia iwayomogi } \\ \text { AED: } & \begin{array}{l}\text { Artemisia iwayomogi extract-supplemented } \\ \text { diet }\end{array} \\ \text { aP2: } & \text { Adipocyte protein } 2 \\ \text { C/EBP } \alpha: & \text { CCAAT/enhancer binding protein } \alpha \\ \text { CD36: } & \text { Cluster of differentiation } 36 \\ \text { FAS: } & \text { Fatty acid synthase } \\ \text { FFA: } & \text { Free fatty acids } \\ \text { GAPDH: } & \text { Glyceraldehyde-3-phosphate dehydrogenase } \\ \text { HFD: } & \text { High-fat diet } \\ \text { HOMA-IR: } & \text { Homeostasis model assessment of insulin } \\ & \text { resistance } \\ \text { IFN } \alpha: & \text { Interferon } \alpha \\ \text { IFN } \beta: & \text { Interferon } \beta \\ \text { IFN } \gamma: & \text { Interferon } \gamma \\ \text { IL-6: } & \text { Interleukin-6 } \\ \text { MCP1: } & \text { Monocyte chemoattractant protein } 1 \\ \text { ND: } & \text { Normal diet } \\ \text { PPAR } \gamma 2: & \text { Peroxisome proliferator-activated receptor } \gamma 2 \\ \text { TG: } & \text { Triglyceride } \\ \text { TNF } \alpha: & \text { Tumor necrosis factor } \alpha . \\ & \end{array}$

\section{Acknowledgments}

This research was supported by the Korea Health $21 \mathrm{R} \& \mathrm{D}$ Project (Project no. A110532), Ministry of Health and Welfare, Republic of Korea, and by Industrialization Support Program for Biotechnology of Agriculture and Forestry (Project no. 810002031SB110), Ministry for Food, Agriculture, Forestry, and Fisheries, Republic of Korea.

\section{References}

[1] S. M. Rangwala and M. A. Lazar, "Transcriptional control of adipogenesis," Annual Review of Nutrition, vol. 20, pp. 535-559, 2000.

[2] H. M. Lakka, D. E. Laaksonen, T. A. Lakka et al., “The metabolic syndrome and total and cardiovascular disease mortality in middle-aged men," Journal of the American Medical Association, vol. 288, no. 21, pp. 2709-2716, 2002.

[3] M. Perley and D. M. Kipnis, "Plasma insulin responses to glucose and tolbutamide of normal weight and obese diabetic and nondiabetic subjects," Diabetes, vol. 15, no. 12, pp. 867-874, 1966.

[4] S. Kim, Y. Jin, Y. Choi, and T. Park, "Resveratrol exerts antiobesity effects via mechanisms involving down-regulation of adipogenic and inflammatory processes in mice," Biochemical Pharmacology, vol. 81, no. 11, pp. 1343-1351, 2011.

[5] T. Yamauchi, H. Waki, J. Kamon et al., "Inhibition of RXR and $\operatorname{PPAR} \gamma$ ameliorates diet-induced obesity and type 2 diabetes," Journal of Clinical Investigation, vol. 108, no. 7, pp. 1001-1013, 2001.

[6] N. D. Wang, M. J. Finegold, A. Bradley et al., "Impaired energy homeostasis in C/EBP $\alpha$ knockout mice," Science, vol. 269, no. 5227, pp. 1108-1112, 1995.

[7] E. Bertin, P. Nguyen, M. Guenounou, V. Durlach, G. Potron, and M. Leutenegger, "Plasma levels of tumor necrosis factoralpha (TNF- $\alpha$ ) are essentially dependent on visceral fat amount in type 2 diabetic patients," Diabetes and Metabolism, vol. 26, no. 3, pp. 178-182, 2000.

[8] J. N. Fain, A. K. Madan, M. L. Hiler, P. Cheema, and S. W. Bahouth, "Comparison of the release of adipokines by adipose tissue, adipose tissue matrix, and adipocytes from visceral and subcutaneous abdominal adipose tissues of obese humans," Endocrinology, vol. 145, no. 5, pp. 2273-2282, 2004.

[9] G. S. Hotamisligil, N. S. Shargill, and B. M. Spiegelman, "Adipose expression of tumor necrosis factor- $\alpha$ : direct role in obesity-linked insulin resistance," Science, vol. 259, no. 5091, pp. 87-91, 1993.

[10] H. Xu, G. T. Barnes, Q. Yang et al., "Chronic inflammation in fat plays a crucial role in the development of obesity-related insulin resistance," Journal of Clinical Investigation, vol. 112, no. 12, pp. 1821-1830, 2003.

[11] M. Maachi, L. Piéroni, E. Bruckert et al., "Systemic low-grade inflammation is related to both circulating and adipose tissue TNF $\alpha$, leptin and IL-6 levels in obese women," International Journal of Obesity, vol. 28, no. 8, pp. 993-997, 2004.

[12] S. J. Kim, Y. Choi, and Y. H. Choi, “Obesity activates toll-like receptor-mediated proinflammatory signaling cascades in the adipose tissue of mice," The Journal of Nutritional Biochemistry, vol. 23, no. 2, pp. 113-122, 2012.

[13] S. H. Kim, C. H. Choi, S. Y. Kim, J. S. Eun, and T. Y. Shin, "Antiallergic effects of Artemisia iwayomogi on mast cell-mediated allergy model," Experimental Biology and Medicine, vol. 230, no. 1, pp. 82-88, 2005.

[14] H. J. Ji, H. K. Yeo, N. H. Lee et al., "A carbohydrate fraction, AIP1, from Artemisia iwayomogi down-regulates Fas gene expression and suppresses apoptotic death of the thymocytes induced by 2,3,7,8-tectrachlorodibenzo-p-dioxin," Biotechnology Letters, vol. 27, no. 4, pp. 253-257, 2005.

[15] J. S. Hwang, H. J. Ji, K. A. Koo et al., "AIP1, a watersoluble fraction from Artemisia iwayomogi, suppresses thymocyte apoptosis in vitro and down-regulates the expression of fas 
gene," Biological and Pharmaceutical Bulletin, vol. 28, no. 5, pp. 921-924, 2005.

[16] Y. Ding, J. A. Kim, S. Y. Yang, W. K. Kim, S. H. Lee, and H. D. Jang, "Antioxidative sesquiterpenes from Artemisia iwayomogi," Notes, vol. 32, no. 9, p. 3493, 2011.

[17] N. Sang-Myung, H. Seung-Shi, O. Duk-Hwan, K. Il-Jun, and L. Sang-Young, "Effects of Artemisia iwayomogi kitamura ethanol extract on lowering serum and liver lipids in rats," Journal of the Korean Society of Food Science and Nutrition, vol. 27, no. 2, pp. 338-343, 1998.

[18] S. Y. Cho, H. W. Jeong, J. H. Sohn, D. B. Seo, and W. G. Kim, "An ethanol extract of Artemisia iwayomogi activates PPARdelta leading to activation of fatty acid oxidation in skeletal muscle," PloS ONE, vol. 7, no. 3, Article ID e33815, 2012.

[19] J. Folch, M. Folch, and G. H. Sloane Stanley, "A simple method for the isolation and purification of total lipides from animal tissues," The Journal of Biological Chemistry, vol. 226, no. 1, pp. 497-509, 1957.

[20] M. Mapfei, J. Halaas, E. Ravussin et al., "Leptin levels in human and rodent: measurement of plasma leptin and ob RNA in obese and weight-reduced subjects," Nature Medicine, vol. 1, no. 11, pp. 1155-1161, 1995.

[21] G. Wang, X. Liu, K. K. Christoffel et al., "Prediabetes is not all about obesity: association between plasma leptin and prediabetes in lean rural Chinese adults," European Journal of Endocrinology, vol. 163, no. 2, pp. 243-249, 2010.

[22] N. Kubota, Y. Terauchi, H. Miki et al., "PPAR $\gamma$ mediates highfat diet-induced adipocyte hypertrophy and insulin resistance," Molecular Cell, vol. 4, no. 4, pp. 597-609, 1999.

[23] A. V. Hertzel and D. A. Bernlohr, "Regulation of adipocyte gene expression by polyunsaturated fatty acids," Molecular and Cellular Biochemistry, vol. 188, no. 1-2, pp. 33-39, 1998.

[24] P. Tontonoz, E. Hu, R. A. Graves, A. I. Budavari, and B. M. Spiegelman, "mPPAR $\gamma 2$ : tissue-specific regulator of an adipocyte enhancer," Genes and Development, vol. 8, no. 10, pp. 1224-1234, 1994.

[25] P. Tontonoz, L. Nagy, J. G. A. Alvarez, V. A. Thomazy, and R. M. Evans, "PPAR $\gamma$ promotes monocyte/macrophage differentiation and uptake of oxidized LDL," Cell, vol. 93, no. 2, pp. 241-252, 1998.

[26] J. Phan, M. Péterfy, and K. Reue, "Lipin expression preceding peroxisome proliferator-activated receptor- $\gamma$ is critical for adipogenesis in vivo and in vitro," Journal of Biological Chemistry, vol. 279, no. 28, pp. 29558-29564, 2004.

[27] H. S. Sul and D. Wang, "Nutritional and hormonal regulation of enzymes in fat synthesis: studies of fatty acid synthase and mitochondrial glycerol-3-phosphate acyltransferase gene transcription," Annual Review of Nutrition, vol. 18, pp. 331-351, 1998.

[28] C. T. Coburn, F. F. Knapp Jr., M. Febbraio, A. L. Beets, R. L. Silverstein, and N. A. Abumrad, "Defective uptake and utilization of long chain fatty acids in muscle and adipose tissues of CD36 knockout mice," Journal of Biological Chemistry, vol. 275, no. 42, pp. 32523-32529, 2000.

[29] I. Tzameli, H. Fang, M. Ollero et al., "Regulated production of a peroxisome proliferator-activated receptor- $\gamma$ ligand during an early phase of adipocyte differentiation in 3T3-L1 adipocytes," Journal of Biological Chemistry, vol. 279, no. 34, pp. 36093-36102, 2004.

[30] G. Boden, "Obesity and free fatty acids," Endocrinology and Metabolism Clinics of North America, vol. 37, no. 3, pp. 635-646, 2008.
[31] H. Ruan, N. Hacohen, T. R. Golub, L. Van Parijs, and H. F. Lodish, "Tumor necrosis factor- $\alpha$ suppresses adipocytespecific genes and activates expression of preadipocyte genes in 3T3-L1 adipocytes: nuclear factor- $\kappa \mathrm{B}$ activation by TNF- $\alpha$ is obligatory," Diabetes, vol. 51, no. 5, pp. 1319-1336, 2002.

[32] T. Suganami, J. Nishida, and Y. Ogawa, "A paracrine loop between adipocytes and macrophages aggravates inflammatory changes: role of free fatty acids and tumor necrosis factor $\alpha$," Arteriosclerosis, Thrombosis, and Vascular Biology, vol. 25, no. 10, pp. 2062-2068, 2005.

[33] J. V. Castell, M. J. Gomez-Lechon, M. David, R. Fabra, R. Trullenque, and P. C. Heinrich, "Acute-phase response of human hepatocytes: regulation of acute-phase protein synthesis by interleukin-6," Hepatology, vol. 12, no. 5, pp. 1179-1186, 1990.

[34] S. A. Burstein, J. Peng, P. Friese et al., "Cytokine-induced alteration of platelet and hemostatic function," Stem Cells, vol. 14, no. 1, pp. 154-162, 1996.

[35] H. Kanda, S. Tateya, Y. Tamori et al., "MCP-1 contributes to macrophage infiltration into adipose tissue, insulin resistance, and hepatic steatosis in obesity," Journal of Clinical Investigation, vol. 116, no. 6, pp. 1494-1505, 2006.

[36] T. Sareneva, S. Matikainen, M. Kurimoto, and I. Julkunen, "Influenza A virus-induced IFN- $\alpha / \beta$ and IL-18 synergistically enhance IFN- $\gamma$ gene expression in human T cells," Journal of Immunology, vol. 160, no. 12, pp. 6032-6038, 1998.

[37] D. E. Moller, "Potential role of TNF- $\alpha$ in the pathogenesis of insulin resistance and type 2 diabetes," Trends in Endocrinology and Metabolism, vol. 11, no. 6, pp. 212-217, 2000.

[38] P. J. Klover, T. A. Zimmers, L. G. Koniaris, and R. A. Mooney, "Chronic exposure to interleukin-6 causes hepatic insulin resistance in mice," Diabetes, vol. 52, no. 11, pp. 2784-2789, 2003.

[39] N. Kamei, K. Tobe, R. Suzuki et al., "Overexpression of monocyte chemoattractant protein-1 in adipose tissues causes macrophage recruitment and insulin resistance," Journal of Biological Chemistry, vol. 281, no. 36, pp. 26602-26614, 2006.

[40] R. Feinstein, H. Kanety, M. Z. Papa, B. Lunenfeld, and A. Karasik, "Tumor necrosis factor- $\alpha$ suppresses insulin-induced tyrosine phosphorylation of insulin receptor and its substrates," Journal of Biological Chemistry, vol. 268, no. 35, pp. 26055-26058, 1993.

[41] B. Cohen, D. Novick, and M. Rubinstein, "Modulation of insulin activities by leptin," Science, vol. 274, no. 5290, pp. 1185-1188, 1996.

[42] Z. Zhao, Y. Hu, Z. Liang, J. P. S. Yuen, Z. Jiang, and K. S. Y. Leung, "Authentication is fundamental for standardization of Chinese medicines," Planta Medica, vol. 72, no. 10, pp. 865-874, 2006.

[43] A. R. Kim, Y. N. Zou, T. H. Park et al., "Active components from Artemisia iwayomogi displaying ONOO-scavenging activity," Phytotherapy Research, vol. 18, no. 1, pp. 1-7, 2004.

[44] H. H. Yu, Y. H. Kim, B. S. Kil, K. J. Kim, S. I. Jeong, and Y. O. You, "Chemical composition and antibacterial activity of essential oil of Artemisia iwayomogi," Planta Medica, vol. 69, no. 12, pp. 1159-1162, 2003.

[45] Y. Ding, C. Liang, S. Y. Yang et al., "Phenolic compounds from Artemisia iwayomogi and their effects on osteoblastic MC3T3E1 cells," Biological and Pharmaceutical Bulletin, vol. 33, no. 8, pp. 1448-1453, 2010.

[46] J. M. Han, H. G. Kim, M. K. Choi et al., "Aqueous extract of Artemisia iwayomogi Kitamura attenuates cholestatic liver fibrosis in a rat model of bile duct ligation," Food and Chemical Toxicology, vol. 50, no. 10, pp. 3505-3513, 2012. 
[47] J. H. Wang, M. K. Choi, J. W. Shin, S. Y. Hwang, and C. G. Son, "Antifibrotic effects of Artemisia capillaris and Artemisia iwayomogi in a carbon tetrachloride-induced chronic hepatic fibrosis animal model," Journal of Ethnopharmacology, vol. 140, no. 1, pp. 179-185, 2012.

[48] E. Shin, K. M. Choi, H. S. Yoo, C. K. Lee, B. Y. Hwang, and M. K. Lee, "Inhibitory effects of coumarins from the stem barks of fraxinus rhynchophylla on adipocyte differentiation in 3T3-L1 cells," Biological and Pharmaceutical Bulletin, vol. 33, no. 9, pp. 1610-1614, 2010.

[49] J. T. Hwang, S. H. Kim, H. J. Hur et al., "Decursin, an active compound isolated from Angelica gigas, inhibits fat accumulation, reduces adipocytokine secretion and improves glucose tolerance in mice fed a high-fat diet," Phytotherapy Research, vol. 26, no. 5, pp. 633-638, 2012.

[50] S. K. Dharmarajan and K. M. Arumugam, "Comparative evaluation of flavone from Mucuna pruriens and coumarin from Ionidium suffruticosum for hypolipidemic activity in rats fed with high Fat diet," Lipids in Health and Disease, vol. 11, article 126, 2012. 


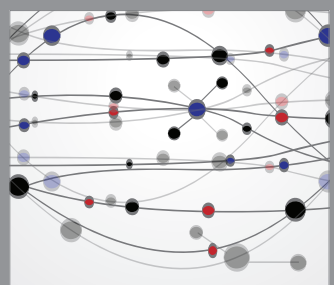

The Scientific World Journal
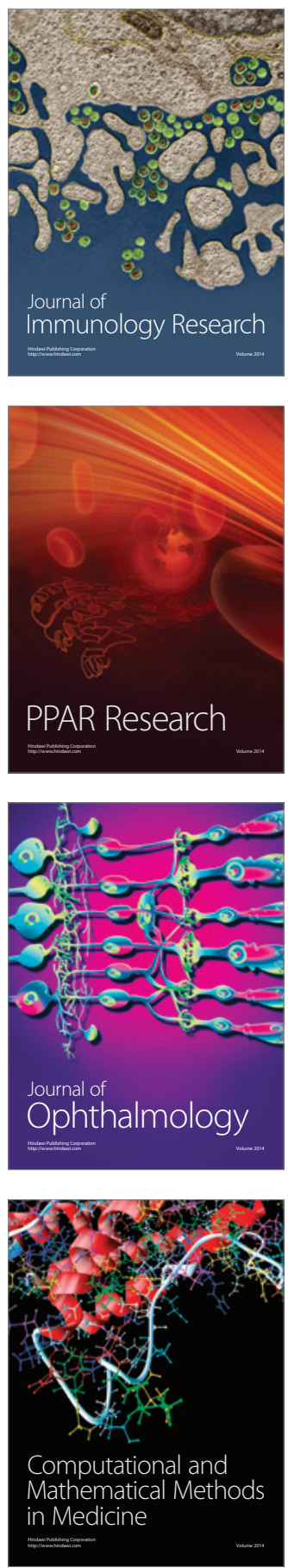

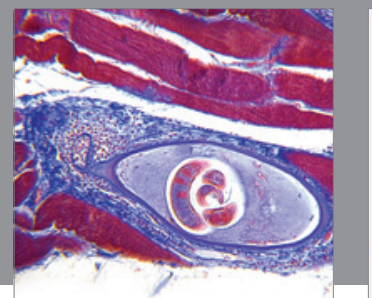

Gastroenterology

Research and Practice
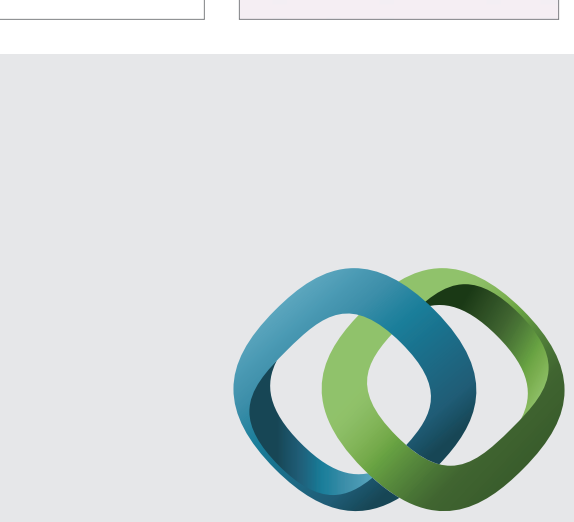

\section{Hindawi}

Submit your manuscripts at

http://www.hindawi.com
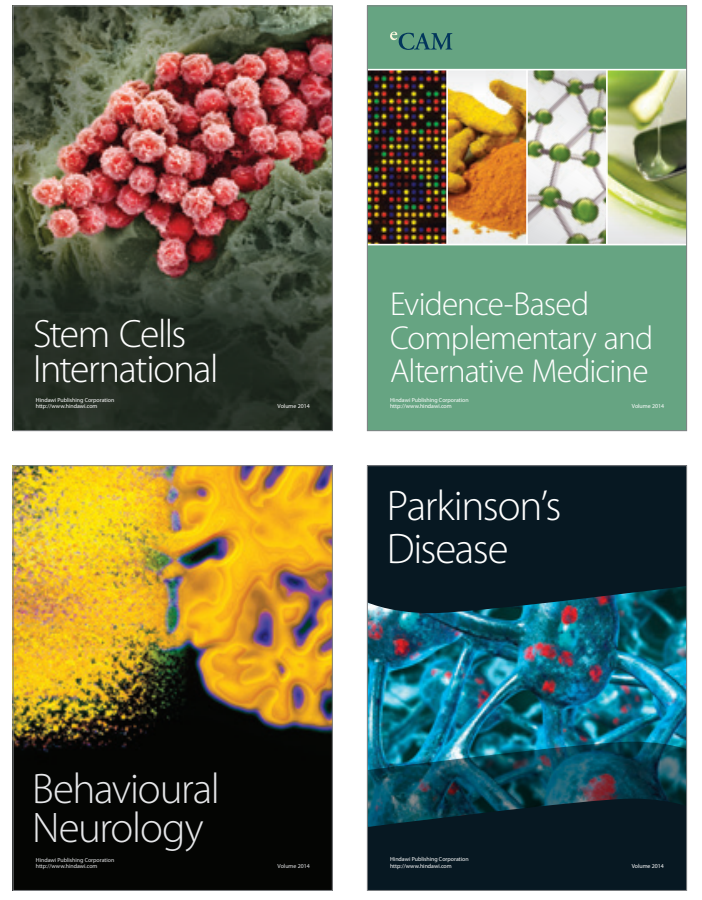
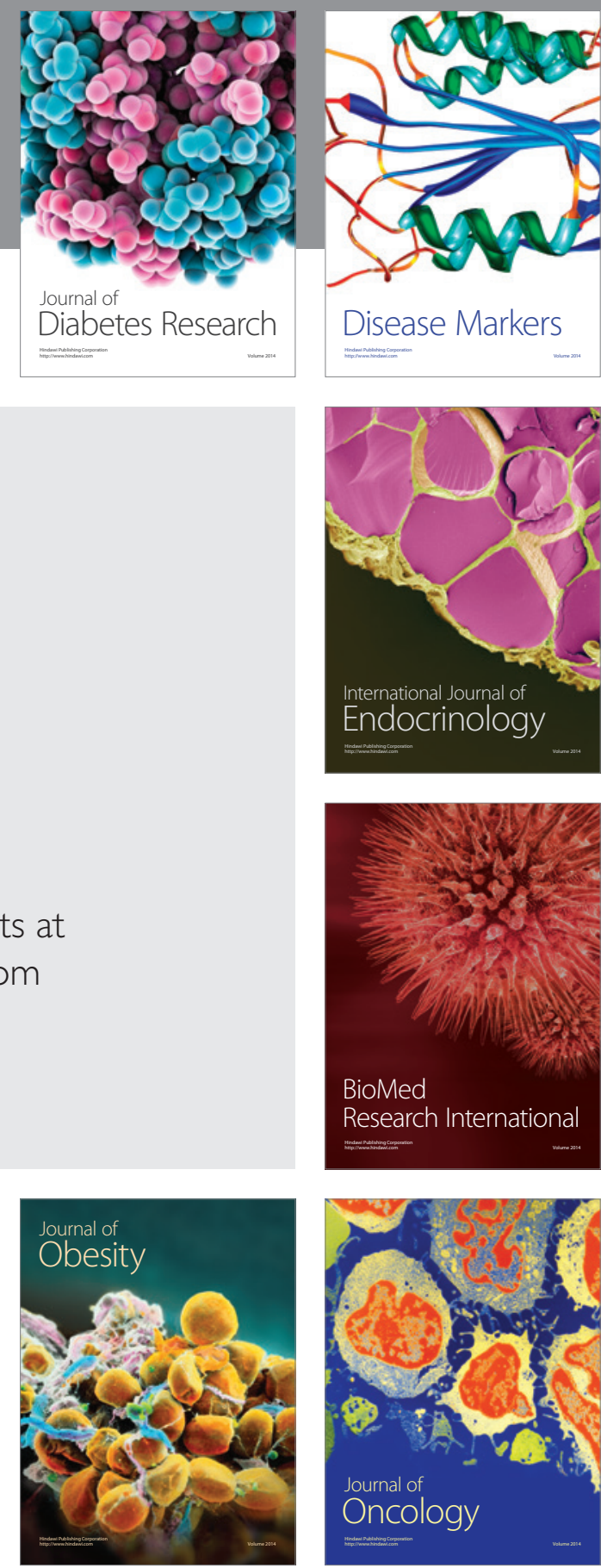

Disease Markers
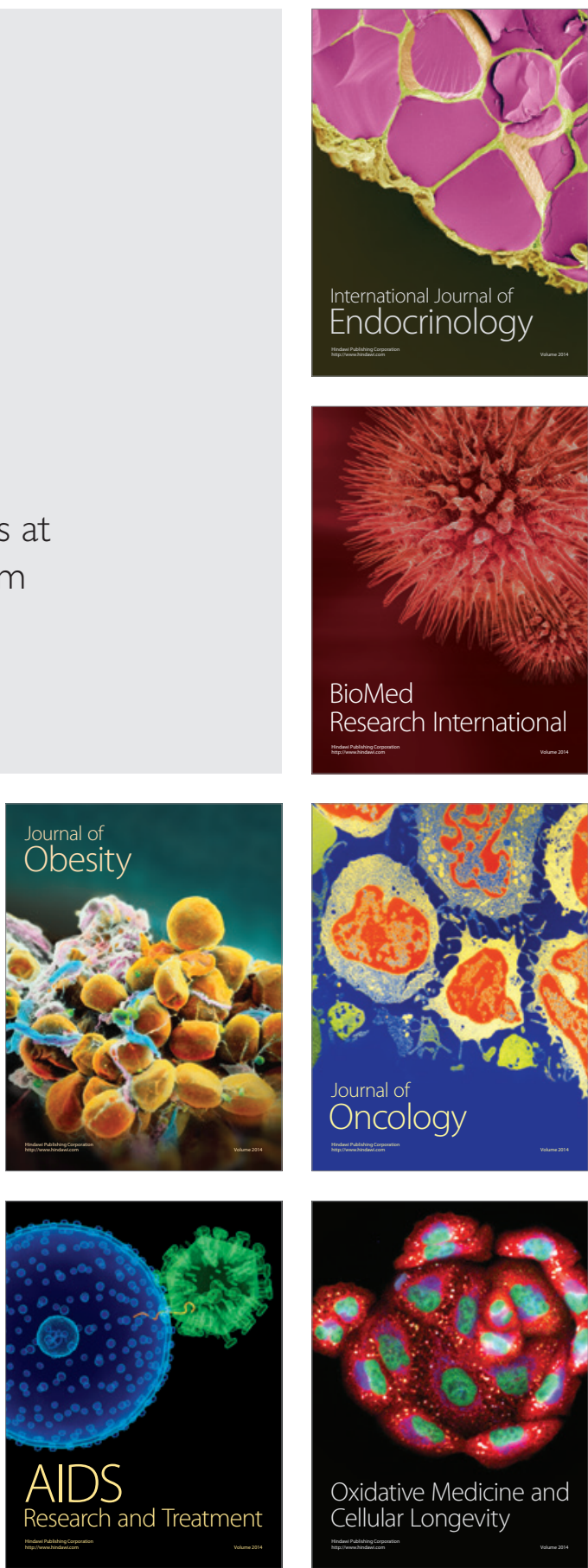